\title{
Гнійна інфекція м'яких тканин таза і стегна, спричинена внутрішньоматковою спіраллю
}

\author{
YU. S. LYSIUK, O. V. ZUBENKOํㅗㄴ, YA. O. SAVCHAK, V. M. PARANCHYSHYN \\ Lviv National Medical University by Danylo Halytskyi \\ Lviv City Communal Clinical Emergency Hospital ${ }^{3}$
}

\section{SOFT TISSUE PURULENT INFECTION OF THE PELVIS AND HIPS CAUSED BY INTRAUTERINE DEVICES}

\begin{abstract}
У статті наведено результати ретроспективного вивчення клінічного випадку тяжкої гнійної інфекції таза і стегна, спричиненої тривалим перебуванням внутрішньоматкової спіралі (ВМС). Акцентовано увагу на діагностиці потенційних внутрішньотазових та позатазових шляхів поширення гнійної інфекції. Застосування ультрасонографії та комп'ютерної томографії дозволило діагностувати поширення нагнійного процесу із бічного параметриту у футляри жирової клітковини та м'язів із формуванням флегмон таза, сідничної та стегнової ділянок. Виконання трьох операційних втручань та видалення ВМС сприяло позитивному результату лікування. Зроблено висновок, що варіабельність внутрішньотазових і позатазових шляхів поширення запального процесу з потенційним формуванням віддалених флегмон вимагає високої поінформованості лікарів різних профілів. Знання цих характеристик гнійної інфекції таза та співпраця лікарів променевої діагностики і лікарів-клініцистів може допомогти своєчасно встановити правильний діагноз і вибрати адекватний метод та об’єм втручання. Комп'ютерна томографія та ультрасонографія $\epsilon$ високоінформативними методами діагностики поширеної гнійної інфекції м’яких тканин таза.
\end{abstract}

The article presents the clinical case of difficult pelvic and femoral purulent infection caused by prolonged use of intrauterine devices (IUD). The research focuses on the diagnosis of potential intrapelvic and extrapelvic ways of the soft tissue infections. Using the computed tomography and ultrasonography allowed to diagnose the spreading of purulent process from parametritis to the gluteal and femoral regions. Three operations and IUD removing helped in effective treatment. Variability in the spreading of purulent process with the potential penetration into iliac, femoral and gluteal areas means that awareness of different specialists is required. Computed tomography and ultrasonography are effective diagnostic methods of widespread purulent infections of the pelvic soft tissues. Computed tomography and ultrasonography are effective diagnostic methods in revealing widespread purulent infections of the pelvic soft tissues. Collaboration between diagnosticians and clinicians can help to make a timely and accurate diagnosis in order to elect an optimal intervention method.

Внутрішньоматкові спіралі (ВМС) є одними із основних факторів ризику виникнення гнійних запальних захворювань придатків матки, а тривале використання ВМС підвищує частоту розвитку гнійнозапальних захворювань таза [1]. Одним із небезпечних для життя запальних ускладнень є розвиток флегмон, однак рідкість даної патології може спричинити труднощі діагностики та помилки в лікуванні.

Мета роботи: акцентувати увагу на діагностиці потенційних внутрішньотазових та позатазових шляхів поширення гнійної інфекції при ускладненні BMC.

Опис клінічного випадку. Пацієнтку віком 55 років госпіталізовано в невідкладному порядку зі скаргами на біль у лівому кульшовому суглобі з іррадіацією у пахвову ділянку, що триває понад 2 місяці, за останні
6 місяців втратила у масі. Діагноз лікаря швидкої допомоги: “Закритий перелом шийки лівого стегна”. При первинному огляді відмічено збільшення в об’ємі верхньої половини лівого стегна із незначним розширенням підшкірних вен, обмеженняі болючість рухів у кульшовому суглобі. При дообстеженні констатовано наявність гіпотонії (АТ - 90/60 мм рт. ст.), анемії (гемоглобін - 78 г/л), лейкоцитозу (10,3 Г/л), підвищення рівня загального фібриногену крові (9,0 г/л); за даними рентгенографії кісток таза та лівого стегна, травматичних змін кісток не виявлено. При ультрасонографії (УСГ) констатовано зниження ехогенності ендометрія і міометрія та наявність внутрішньоматкового рідинного утвору діаметром 28 мм. Хвору проконсультував гінеколог: гінекологічних скарг не висуває, огляд недостатньо інформативний 
(внаслідок болючості в кульшовому суглобі). У зв’язку із неманіфестною симптоматикою пацієнтку додатково проконсультували уролог, невропатолог, травматолог - патології не виявлено. Встановлено попередній діагноз флеботромбозу лівого стегна, остеомієліту стегнової кістки, хвору госпіталізовано в хірургічний відділ.

Впродовж наступної доби констатовано збільшення в 1,5 раза об'єму лівого стегна із болючим випинанням по задній поверхні, запідозрено туберкульозне ураження лівого кулышового суглоба або саркому лівого стегна із розпадом та нагноєнням. Хвору додатково проконсультував онколог - даних за онкопатологію не виявлено. За результатами контрольного аналізу крові, утримувалися анемія (гемоглобін - 67 г/л), лейкоцитоз (13,8 - Г/л) із зсувом вліво (паличкоядерні нейтрофіли - 20 \%).

При повторній УСГ відмічено ознаки хронічного гепатиту, спленомегалії, портальної гіпертензії та абсцесу в проекції лівого кульшового суглоба. Для уточнення діагнозу виконано комп'ютерну томографію таза (рис. 1, 2), стверджено збільшення в об’ємі клубово-стегнової ділянки внаслідок по-

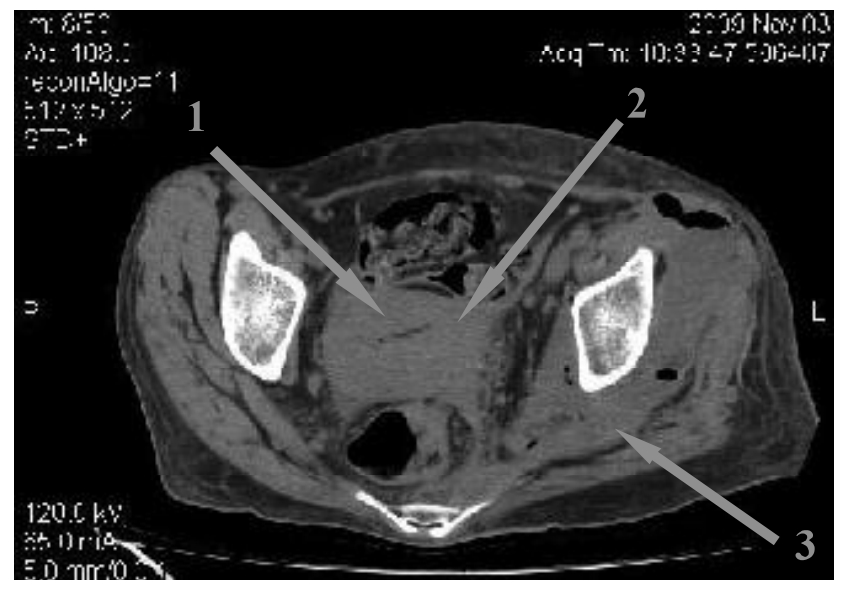

Рис. 1. КТ таза: 1 - внутрішньоматкова спіраль, 2 бічний параметрит, 3 - флегмона затульного м’яза.

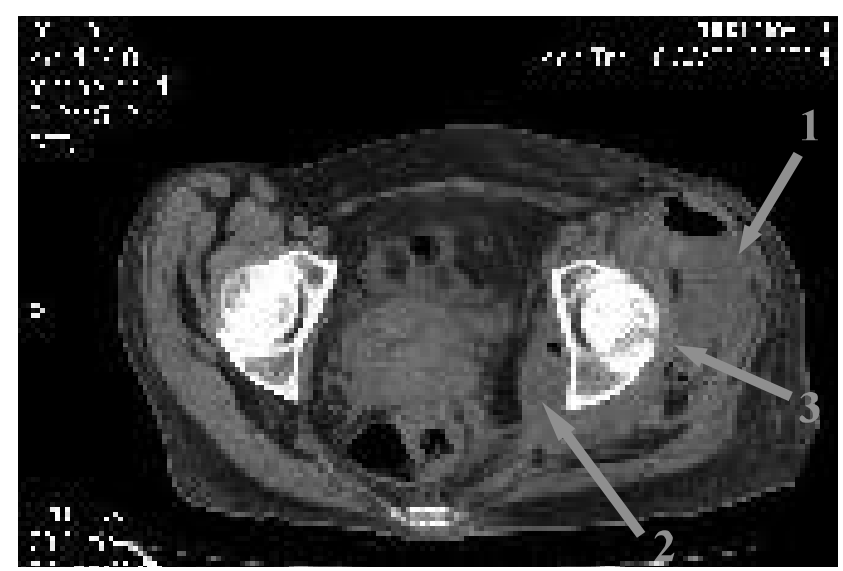

Рис. 2. КТ таза: 1 - флегмона сідничної ділянки, 2 флегмона затульного м’яза, 3 - параартикулярна флегмона. товщення м'язів, відмічено наявність міхурців газу в проекції внутрішнього затульного м’яза, скупчення рідини (гнійний вміст) 32×39 мм із міхурцями газу в проекції сідничного м’яза на рівні кульшового суглоба та інфільтрацію заочеревинного простору до широкої зв'язки матки зліва.

Діагностовано інфекційний запальний процес у м'яких тканинах лівої нижньої кінцівки і виконано операційне втручання - розкриття та дренування субфасціальної параартикулярної флегмони лівого стегна.

У післяопераційному періоді мали місце прояви помірної гіпотонії та анемії; продовжували протизапальну терапію, двічі проведено гемотрансфузію. На 5-ту післяопераційну добу у хворої розвинувся епізод тоніко-клонічних судом (вперше у житті) із втратою свідомості, її проконсультували невропатолог та кардіолог, при комп'ютерній томографї голови патологічних змін не виявлено, висновок ехокардіографії - ознаки “анемічного серця”.

На десятий день госпіталізації при контрольній УСГ ознак тромбозу магістральних вен не виявлено, водночас у ділянці передньо-медіальної поверхні верхньої третини лівого стегна візуалізовано велике рідинне включення. На підставі результатів дообстеження виконано повторне хірургічне втручання - розкрито міжм'язову флегмону верхньої третини стегна.

У подальшому, враховуючи дані повторної УСГ (запідозрено гнійний процес у заочеревинному просторі), пацієнтку двічі проконсультували гінекологи, діагностовано параметрит, ВМС (встановлену 25 років тому). На 13-й день госпіталізації при контрольній УСГ стверджено наявність гнійного вогнища між листками широкої зв'язки матки та заочеревинного простору зліва, виконано третє операційне втручання - розкрито внутрішньотазову флегмону клубового м’яза. На 17-й день госпіталізації проведено діагностичне вишкрібання стінок порожнини матки та видалено ВМС. Подалыший перебіг без ускладнень, пацієнтку виписано в задовільному стані на 35-й день після першої операції.

Обговорення. Відомо, що внутрішньоматкова спіраль здатна порушувати нормальні захисні механізми ендометрія та може спричинювати розвиток інфекцій [2]. При використанні ВМС понад 5 років різко підвищується частота таких гнійносептичних ускладнень, як параметрит, перитоніт, сепсис [1]. Окрім того, довготривале використання ВMC приводить до серйозного ризику інфекції таза із млявим перебігом [3]. Водночас анатомічні й фізіологічні особливості порожнини таза створюють сприятливі умови для поширення гнійної інфекції [4], зокрема боковий параметрій розміщується в основі 
широкої зв’язки матки між її листками і переходить безпосередньо в пристінкову клітковину [5].

Променеві візуалізаційні методи можуть бути досить інформативними при діагностиці ускладнень ВМС, оскільки мідний стрижень спіралі $\epsilon$ гіперехогенним при УСГ та рентгеноконтрастним [6]. Однак є повідомлення, що у 4,76 \% випадків рентгенодіагностика була помилковою при пошуку хвоста ВМС - стверджено внутрішньоматкове положення спіралі, хоча при лапароскопії виявлено iii позаматкове розташування [7]. Застосування комп’ютерної та магнітно-резонансної томографії показано при позаматкових ускладненнях ВMC та діагностиці абсцесів, i вони можуть бути рекомендовані у подальшому веденні пацієнтів [8].

Нагнійні процеси таза мають тяжкий перебіг у зв’язку з особливостями фасціальних структур, що визначають формування множинних внутрішньота позатазових шляхів поширення. Основні клітковинні простори таза хоч і обмежені фасціями, проте не забезпечують відмежування гнояків, тому через природні щілини у фасціях, а також при їх руйнуванні запальний процес може поширюватися з одного простору в інший [5]. Ось чому гнійні запливи із параметрія можуть поширюватися за ходом сечоводів і судин яєчників у клітковину заочеревинного простору, клубової ямки, сідничної ділянки та пахвинний канал [5].

Однак випадків подібного віддаленого поширення нагнійного процесу, спричиненого ВМС, із залученням 9 можливих шляхів поширення в доступній літературі не знайдено. В нашому випадку нагнійний процес із бічного параметриту перейшов у футляри жирової клітковини та м'язів таза із формуванням внутрішньотазових флегмон (клубового

\section{СПИСОК ЛІТЕРАТУРИ}

1. Вербицкий В. С. Риск развития гнойных воспалительных заболеваний придатков матки при применении внутриматочной контрацепции / В. С. Вербицкий // Медицинская панорама. - 2005. - № 8. - С. 32-34.

2. Bacteriological colonization of uterine cavity: role of tailed intrauterine contraceptive device / R. A. Sparks, B. G. Purrier, P. J. Watt, M. Elstein. // British medical journal. - 1981. - № 282. - P. 1189-1191.

3. Toglia M. R. Tubo-Ovarian Abscess Formation in Users of Intrauterine Devices Remote From Insertion: A Report of Three Cases / M. R. Toglia, J. I. Schaffer // Infectious Diseases in Obstetrics and Gynecology. - 1996. - № 2. - P. 85-88.

4. Кондратенко П. Г. Хирургическая инфекция : практическое руководство. / П. Г. Кондратенко, В. В. Соболев. - Донецк, 2007. -512 c. м'яза, затульного м'яза) 3 подальшим проникненням через затульний отвір на стегно і сідничну ділянку та формуванням віддалених флегмон (параартикулярної, сідничної, глибоких м'язових флегмон привідної, передньої та задньої груп стегна).

Клінічна діагностика нагнійних процесів тазової локалізації буває утруднена у зв'язку із розвинутим масивом м'язів та особливостями будови органів таза i його клітковинних просторів [5]. Сучасні променеві методи діагностики (УСГ, КТ) є достатньо інформативними для виявлення великих об'ємних нагнійних процесів [9]. Застосування візуалізаційних методів діагностики та обізнаність із шляхами поширення нагнійних процесів тазової локалізації $€$ особливо важливими, оскільки необхідно визначити не тільки локалізацію первинних вогнищ, але також можливий перехід запального процесу з однієї анатомічної ділянки таза в іншу і на основі цього вибрати більш раціональний об’єм і характер операції [5].

Знання цих характеристик і співпраця лікарівдіагностів та лікарів-клініцистів можуть допомогти своєчасно встановити правильний діагноз і вибрати адекватний метод і об’єм втручання.

Висновки. 1. Тривале перебування ВМС може ускладнитися гнійною інфекцією м'яких тканин таза.

2. Варіабельність внутрішньотазових і позатазових шляхів поширення запального процесу з потенційним проникненням у клубово-сідничну і стегнову ділянки вимагає високої поінформованості та настороженості у лікарів різних профілів.

3. Комп’ютерна томографія та ультрасонографія $є$ високоінформативними методами діагностики поширеної гнійної інфекції м’яких тканин таза.

5. Гостищев В. К. Гнойная хирургия таза : руководство для врачей / В. К. Гостищев, Л. П. Шалчкова. - М. : Медицина, 2000. -288 c.

6. Migration of Intrauterine Devices: Radiologic Findings and Implications for Patient Care / H. E. Boortz, J. A. Margolis Daniel, N. Ragavendra [et al.]. // RadioGraphics. - 2012. - № 2. P. 335-352.

7. The value of X-ray with uterine sound in the diagnosis of IUDs with missing tails / A. A. Kady, H. A. Rifat, M. A. Hosseiny, G. Y. Gafar // Advances in Contraception. - 1986. - № 2. - P. 161-167.

8. Peri N. Imaging of Intrauterine Contraceptive Devices / N. Peri, D. Graham, D. Levine // Journal of Ultrasound in Medicine. 2007. - № 10. - P. 1389-1401.

9. Imaging of Soft Tissue Infections / D. W. Struk, P. L. Munk, M. J. Lee [et al.] // Radiologic Clinics. - 2001. - № 2. - P. 277-303. 